\title{
PERKEMBANGAN DAN PENERIMAAN MASYARAKAT TERHADAP PERBANKAN SYARIAH DI INDONESIA
}

Uswatun Khasanah

Universitas Islam Negeri Sunan Kalijaga Yogyakarya, Indonesia

Email: 19203010075@student.uin-suka.ac.id

\begin{abstract}
Abstrak
Bank Syariah merupakan sebuah lembaga perbankan yang menerapkan prinsipprinsip syariah pada aspek kegiatannya. Sebagaimana diatur dalam Undang-Undang Nomor 21 Tahun 2008 tentang Perbankan Syariah, bank ini terdiri atas Bank Umum Syariah dan Bank Pembiayaan Rakyat Syariah. Artikel ini bertujuan untuk mendeskripsikan sejarah pertumbuhan hingga perkembangan perbankan syariah saat ini di Indonesia. Begitupula pemetaan serta penerimaaan masyarakat Indonesia terhadap sistem perbankan syariah. Artikel ini merupakan penelitian Kepustakaan (library research) dengan pendekatan sejarah. Hasil kajian ini menunjukkan adanya perkembangan yang cukup baik pada bank syaiah. Hal ini dibuktikan dengan data statistik yang menunjukkan adanya peningkatan aset, Pembiayaan yang diberikan (PYD) dan Dana Pihak Ketiga (DPK) setiap tahunnya dengan rata-rata pertumbuhan aset $14,97 \%$ dalam 5 tahun terakhir. Meskipun demikian persentase pasar (market share) perbankan syariah hanya 6,51\% dari seluruh market share bank konvensional. Kata Kunci: Perbankan Syariah, Market Share.
\end{abstract}

\section{A. Pendahuluan}

Perkembangan agama Islam yang semakin meluas membawa dampak pada banyak bidang dalam tatanan kehidupan. Salah satunya dari segi perekonomian. Sejak awal tahun 70-an gerakan Islam di tingkat nasional telah memasuki bidang ekonomi dengan memperkenalkan sistem ekonomi Islam sebagai alternatif terhadap sisitem kapitalis da sistem sosial.

Cikal bakal penerapan sistem ekonomi syariah ini tercatat mulai dilakukan di Pakistan dan Malaysia sekitar tahun 1940-an. Yakni pengelolaan dana haji dengan sistem melalui profit and loss sharing. Selanjutnya sejarah perbankan syariah pertama adalah pendirian Islamic Rural Bank di desa Mit Ghamr Mesir tahun 1963. Di tahun-tahun selanjutnya sistem ekonomi syariah sudah mulai banyak berkembang, meskipun masih banyak kendala karena pergolakan politik.

Salah satu tonggak perkembangan perbankan syariah adalah didirikannya Islamic Development Bank (IDB) pada tahun 1975 yang berpusat di Jeddah. ${ }^{1}$ Rencana pendirian bank ini dimulai dengan adanya sidang Menteri Luar Negeri yang diselenggarakna oleh OKI di Karachi, Pakistan pada tahun 1970. Bank pembangunan yang menyerupai bank dunia (The World Bank) ini dibentuk oleh Organisasi Konferensi Islam (OKI) dengan anggota dari beberapa negara Islam termasuk Indonesia.

\footnotetext{
${ }^{1}$ Adiwarman Karim, Bank Islam: Analisis Fiqih dan Keuangan, (Jakarta: PT. Raja Grafindo, 2007), hlm. xiv
} 
Sejak berdirinya IDB ini kemudian muncul bank-bank Islam di seluruh dunia. Termasuk di kawasan Eropa dan Asia. Di negara Asia Tenggara sendiri perkembangan bank syariah diawali sekitar tahun 80-an di Malaisya, dengan berdirinya Bank Islam Malaysia Berhad (BIMB) pada tahun 1983. Bank ini berhasil mendapat perhatian masyarakat berkat kerja sama dengan Lembaga Urusan dan Tabungan Haji. Sehingga berhasil mengembangkan 70 cabang di seluruh Malaysia.

Sementara itu di Indonesia, secara kelembagaan Bank Islam pertama ialah Bank Muamalat Indonesia (BMI). Bank ini didirikan pada tahun 1991. Meskipun pemikiran mengenai pendirian bank ini sudah ada sejak tahun 1970-an, namun baru terlaksana pada tahun 1991. Hal ini dikarenakan faktor politik, yaitu bahwa pendirian bank Islam dianggap sebagai sabagian dari citacita mendirikan Islam. Selanjunya pasca berdirinya BMI ini disusul oleh bank-bank konvensional yang membuka jendela syariah (syariah window) dan menjalankan kegiatan usahanya melalui produk-produk dengan prinsip syariah.

Hingga saat ini eksistensi keberadaan bank syariah semakin berkembang dan dikenal di kalangan masyakat. Data terakhir menunjukkan ada sejumlah 197 lembaga terkait perbankan syariah dengan 3.053 kantor di seluruh Indonesia. ${ }^{2}$ Lembaga ini meliputi Bank Umum Syariah, Bank Usaha Syariah dan Bank Pembiayaan Rakyat Syariah.

Namun demikian, tingkat penerimaan masyarakat belum sepenuhnya terbuka. Terbukti dari perbandingan jumlah nasabah yang sangat signifikan antara bank konvensional dan bank syariah. Total rekening simpanan per Agustus 2019 mencapai 292,96 juta rekening ${ }^{3}$, dengan jumlah rekening dalam perbankan syariah per Oktober 2019 hanya mencapai 31,89 juta. ${ }^{4}$ Kemudian data terakhir per Desembe 2020 jumlah DPK mencapai Rp475,79 triliun dengan total rekening 36,43 juta.

Sehubungan dengan latar belakang di atas penulis tertarik untuk membahas bagaimana sejarah Perbankan Syariah di Indonesia dan Tingkat Penerimaan Masyarakat terhadap Perbankan Syariah serta hal-hal terkait dengan perkembangan Lembaga Keuangan Syariah.

\section{B. PEMBAHASAN}

\section{Sejarah Perbankan Syariah}

Secara umum bank adalah lembaga yang melaksanakan tiga fungsi utama, yaitu menerima simpanan, meminjamkan uang dan memberikan jasa pengiriman uang. ${ }^{5}$ Pada dasarnya sejarah Perbankan Syariah sudah dimulai sejak zaman Rasulullah saw dan para sahabat. Namun pada masa

\footnotetext{
${ }^{2}$ Snapshot Perbankan Syariah OJK Periode Desember 2019

3 "Per Agustus 2019, jumlah rekening simpanan di bank mencapai 292,96 juta rekening," https://keuangan.kontan.co.id/news/per-agustus-2019-jumlah-rekening-simpanan-di-bank-mencapai-29296-jutarekening?page $=$ all akses tanggal 10 Maret 2020

4 "Per Oktober, OJK Catat Jumlah Nasabah Bank Syariah Capai 31,89 Juta," https://www.merdeka.com/uang/per-oktober-ojk-catat-jumlah-nasabah-bank-syariah-capai-3189-juta.html akses tanggal 9 Maret 2020.

${ }^{5}$ Adiwarman Karim, Bank Islam: Analisis Fiqih dan Keuangan...hlm. 18.
} 
ini masih persifat sederhana dan berdasarkan kepercayaan. Praktiknya seperti menerima penitipan harta, meminjamkan uang dan melalukan pengiriman.

Selanjutnya pada masa Bani Umayyah dan Abbasiyah fungsi perbankan mengalami perubahan, dari yang semula satu orang melakukan satu fungsi kemudian pada masa ini tiga fungsi dilakukan oleh satu individu. ${ }^{6}$ Perbankkan mulai berkembang pesat pada masa ini, dimana hampir setiap wazir (menteri) mempunyai bankir sendiri. Selain itu kemajuan praktik perbankan juga ditandai dengan beredarnya saq (cek) dengan luas sebagai media pembayaran. Bahkan peranan bankir telah meliputi tiga aspek menerima deposit, menyalurkannya dan mentransfer uang.

Sementara dalam perkembangan berikutnya, praktik ekonomi Islam sempat terputus karena bangsa Eropa menjalankan praktik perbankan menggunakan instrumen bunga. Ketika mengalami masa renaissance bangsa Eropa melakukan penjajahan ke seluruh penjuru dunia, sehingga aktivitas perekonomian dunia didominasi oleh bangsa-bangsa Eropa.

Hingga akhirnya lahirlah kembali cikal bakal penerapan sistem ekonomi syariah yang mulai dilakukan di Pakistan dan Malaysia sekitar tahun 1940-an. Yakni pengelolaan dana haji dengan sistem melalui profit and loss sharing. Kemudian berlanjut pada pendirian bank syariah pertama yakni pendirian Islamic Rural Bank di desa Mit Ghamr Mesir tahun 1963. Bank ini mendapat sambutan yang cukup hangat di Mesir, terutama dari kalangan petani dan masyarakat pedesaan. Akan tetapi pada tahun 1967 Mit Ghamr dilikuidasi karena tidak mendapat dukungan politik. Pada tahun yang sama ketika Mit Ghamr didirikan, Indonesia dilanda perekonomian yang sangat kacau. Yakni tahun 1963 dimana kondisi politik Indonesia masih era revolusi (1960-1969). ${ }^{7}$

Salah satu tonggak perkembangan perbankan syariah adalah didirikannya Islamic Development Bank (IDB) pada bulan Oktober 1975 yang berpusat di Jeddah. ${ }^{8}$ Bank pembangunan yang menyerupai bank dunia (The World Bank) ini dibentuk oleh Organisasi Konferensi Islam (OKI) yang beranggotakan 22 negara Islam pendiri, termasuk Indonesia. Bank ini menyedikan bantuan finansial untuk membantu mendirikan bank Islam di negara-negara anggota serta melakukan penelitian ekonomi, perbankan dan keuangan Islam. Kini bank ini memiliki 57 negara anggota dengan pemegang saham terbesar dalah Arab Saudi.

Sejak berdirinya IDB ini kemudian muncul bank-bank Islam di seluruh dunia. Termasuk di kawasan Eropa dan Asia. Beberapa negara seperti Pakistan, Iran dan Sudan bahkan mengubah seluruh sistem keuangan menjadi sistem nir-bunga.. Di negara Asia Tenggara sendiri perkembangan bank syariah diawali sekitar tahun 80-an di Malaisya, dengan berdirinya Bank Islam Malaysia Berhad (BIMB) pada tahun 1983.

Sementara itu di Indonesia, secara kelembagaan Bank Islam pertama ialah Bank Muamalat Indonesia (BMI). Bank ini didirikan pada tahun 1991. Meskipun pemikiran mengenai pendirian

\footnotetext{
${ }^{6}$ ibid, hlm. 20.

${ }^{7}$ Ahmad Dahlan, Bank Syariah: Teoritik, Praktik, Kritik (Yogyakarta, Teras, 2012), hlm. 11.

${ }^{8}$ Adiwarman Karim, Bank Islam: Analisis Fiqih dan Keuangan...m. xiv
} 
bank ini sudah ada sejak tahun 1980-an', namun kemudian baru terealisasi pada tahun 1991. Pada masa itu beberapa uji coba dengan skala terbatas telah dilakukan. Di antaranya pendirian Baitu Tamwil-Salman di Bandung dan koperasi Ridho Gusti di Jakarta. ${ }^{10}$ Bank Muamalat Indonesia ini secara resmi mulai beroperasi pada tahun 1992.

Selanjunya pasca berdirinya BMI ini disusul oleh bank-bank konvensional yang membuka jendela syariah (Islamic Window) dan menjalankan kegiatan usahanya melalui produk-produk dengan prinsip syariah. Melalui Islamic Window ini bank-bank konvessional dapat memberikan jasa pembiayaan syariah pada melalui produk-produk yang bebas dari unsur riba, gharar dan maysyir dengan terlebih dahulu membuka UnitUsaha Syariah (UUS).

Hingga saat ini eksistensi keberadaan bank syariah semakin berkembang dan dikenal di kalangan masyakat. Data terakhir menunjukkan ada sejumlah 197 lembaga terkait perbankan syariah dengan 3.053 kantor di seluruh Indonesia. ${ }^{11}$ Lembaga ini meliputi Bank Umum Syariah, Bank Usaha Syariah dan Bank Pembiayaan Rakyat Syariah

Sedangkan secara yuridis, perundang-uandangan mengenai perbankan syariah dimulai dengan diundangkannya Undang-Uandang Nomor 7 Tahun 1992 Tentang Perbankan. Dimana di dalamnya memuat ketentuan-ketentuan yang secara eksplisit memperbolehkan pengelolaaan bank berdasarkan prinsip bagi hasil. Hal ini juga ditegaskan melalui Peraturan Pemerintah Nomor 72 Tahun 1992 Tentang Bank Berdasarkan Prinsip Bagi Hasil. Kemudian lahirlah Undang-Undang Nomor 10 Tahun 1998 yang merupakan amandemen dari Undang-Undang Nomor 7 Tahun 1992 Tentang Perbankan. Dalam undang-undang ini secara tegas membedakan adanya Bank Konvensional dan Bank Syariah.

Sejauh ini Undang-undang terbaru terkait lembaga keuangan syariah ini ialah UndangUndang Nomor 21 Tahun 2008 tentang Perbankan Syariah. Dimana di dalamnya dijelaskan secara rinci pengertian, prinsip dan tujuan perbankan syariah. Melalui undang-undang ini diharapkan perkembangan perbankan syariah akan berlangsung lebih cepat dan lebih baik.

Secara umum perkembangan Bank Syariah di Indonesia dapat kita lihat pada tabel berikut ini: ${ }^{12}$

Tabel 1.

Perkembangan Perbankan Syariah di Indonesia

\begin{tabular}{|l|l|}
\hline Tahun & \multicolumn{1}{|c|}{ Keterangan } \\
\hline $\mathbf{1 9 8 0}$ & $\begin{array}{l}\text { Muncul ide dan konsep lembaga keuangan syariah. Di tahun ini juga } \\
\text { dilakukan uji coba BMT Salman di Bandung dan Koperasi Ridho. }\end{array}$ \\
\hline
\end{tabular}

${ }^{9}$ Muhammad Sadi Is, Konsep Hukum Perbankan Syariah: Pola Relasi Sebagai Institusi Intermediasi dan Agen Investasi (Malang: Setara Press, 2015), hlm. 30.

10 Andri Seomitra, Bank dan Lembaga Keuangan Syariah (Jakarta: Kencana, 2009), hlm. 63. Lihat juga Muhammad Syafi'i Antonio, Bank Syariah Suatu Pengenalan Umum (Bogor: BI Bekerja Sama dengan Tazkia Institute, 1999), hlm. 237.

${ }^{11}$ Snapshot Perbankan Syariah OJK periode Desember 2020

12 Andri Seomitra, Bank dan Lembaga Keuangan Syariah ... hlm. 63-66. Lihat juga Muhammad Sadi Is, Konsep Hukum Perbankan Syariah: Pola Relasi Sebagai Institusi Intermediasi... hlm. 34-35. 


\begin{tabular}{|c|c|}
\hline 1988 & $\begin{array}{l}\text { Dikeluarkan Pakto (Paket Kebijakan Oktober), yakni kebijakan yang } \\
\text { mengatur deregulasi industri perbankan yang memungkin pendirian bank } \\
\text { baru selain bank konvensional. }\end{array}$ \\
\hline 1990 & $\begin{array}{l}\text { Lokakarya MUI dimana para peserta sepakat mendirikan Bnak Syariah di } \\
\text { Indonesia. }\end{array}$ \\
\hline 1991 & $\begin{array}{l}\text { Pendirian bank-bank perkreditan rakyat dengan basis sistem Islam, } \\
\text { seperti: } \\
\text { Bank Perkreditan Rakyat Syariah (BPRS) Berkah Amal Sejahtera dan } \\
\text { BPRS Dana Mardhatillah di Bandung (19 Agustus 1991) } \\
\text { BPRS Amanah Rabaniah di Bandung (24 Oktober 1991) } \\
\text { BPRS Hareukat di Aceh (10 November 1991) }\end{array}$ \\
\hline$\overline{1991}$ & $\begin{array}{l}\text { (1 November 1991) Penandatanganan akta pendirian PT. Bank Muamalat } \\
\text { Indonesia. Pada saat penandatangan ini terkumpul pembelian saham } \\
\text { sebesar Rp. } 84 \text { Milyar. } \\
\text { (3 Oktober 1991) acara silaturrahmi Presiden di Istana Bogor, diperoleh } \\
\text { komitmen modal setor awas sebesar Rp.106. } 126.382,00^{13}\end{array}$ \\
\hline 1992 & $\begin{array}{l}\text { Bank Muamalat Indonesia (BMI) mulai beroperasi pada tanggal } 1 \text { Mei } \\
1992\end{array}$ \\
\hline 1992 & $\begin{array}{l}\text { Lahirnya Undang-Undang Nomor } 7 \text { Tahun } 1992 \text { Tentang Perbankan yang } \\
\text { mengakomodasi perbankan dengan prinsip bagi hasil baik bank umun } \\
\text { maupun BPRS. }\end{array}$ \\
\hline 1998 & $\begin{array}{l}\text { Keluar Undang-Undang Nomor } 10 \text { Tahun } 1998 \text { tentang perubahan } \\
\text { Undang-Undang Nomor } 7 \text { Tahun } 1992 \text { yang mengakui keberadaan Bank } \\
\text { Syariah dan Bank Konvensional serta memperkenankan bank } \\
\text { konvensional membuka kantor cabang syariah. }\end{array}$ \\
\hline 1999 & $\begin{array}{l}\text { Keluar Undang-Undang Nomor } 23 \text { Tahun } 1999 \text { tentang Bank Indonesia } \\
\text { yang mengakomodasi kebijakan moneter berdasarkan prinsip syariah, } \\
\text { dimana BI bertanggung jawab terhadap pengaturan dan pengawasan Bank } \\
\text { Konvensiaonal dan Bank Syariah. } \\
\text { Pada tahun ini dibuka cabang kantor bank syariah untuk pertama kali }\end{array}$ \\
\hline 2000 & $\begin{array}{l}\text { Bi mengeluarkakan regulasi operasional dan kelembagaan Bank Syariah } \\
\text { dimana BI menetapkan peraturan kelembagaan Bank Syariah, } \\
\text { pengembangan Pasar Uang Antar Bank Syariah (PUAS), dan Sertifikat } \\
\text { Wadiah Bank Indonesia (SWBI) sebaga instrumebn pasar uang syraiah. }\end{array}$ \\
\hline 2001 & $\begin{array}{l}\text { Pendirian unit biro Perbankan Syariah di Bank Indonesia untuk } \\
\text { menangani Perbankan Syariah. }\end{array}$ \\
\hline 2002 & $\begin{array}{l}\text { Peraturan BI Nomor } 4 / 1 / 2002 \text { mengenai pengenaan pembuktian } \\
\text { bersihcabang syaraih yang merupakan penyempurnaan jarinagan kantor } \\
\text { cabang syariah. }\end{array}$ \\
\hline 2004 & $\begin{array}{l}\text { Keluar Undang-Undang Nomor } 3 \text { Tahun } 2004 \text { tentang perubahan } \\
\text { Undang-Undang Nomor } 23 \text { Tahun } 1999 \text { yang semakin mempertegas } \\
\text { penetapan kebijakan moneter dengan prinsip syariah. }\end{array}$ \\
\hline
\end{tabular}

${ }^{13}$ Nurul Huda dan Mohamad Heykal, Lembaga Keuangan Islam: Tinjauan Teoritis dan Praktis ( Jakarta: Kencana, 2010), hlm. 33. Lihat juga Muhammad Syafi'i Antonio, Bank Syariah Suatu Pengenalan Umum... hlm. 237. 


\begin{tabular}{|l|l|}
\hline 2006 & $\begin{array}{l}\text { Pemberian layanan syariah semakin dipermudah dengan } \\
\text { diperkenalkannya konsep office chaneling, yakni semacam counter } \\
\text { layanan syariah yang terdaapat di kantor cabang / kantor pembantu bank } \\
\text { konvensional yang sudah memiliki UUS. }\end{array}$ \\
\hline 2008 & $\begin{array}{l}\text { Pada tanggal 16 Juli 2008 disahkan Undang-Undang Nomor 21 Tahun } \\
2008 \text { tentang Perbankan Syariah yang memberikan landasan hukum } \\
\text { industri Perbankan Syariah nasional. Selama lima tahun terakhir aset } \\
\text { Perbankan Syariah tumbuh di atas 65\% per tahun, namun paasrnya secara } \\
\text { nasioanan masih di bawah 5\%. }\end{array}$ \\
\hline
\end{tabular}

\section{Pemetaan dan Segmentasi Pasar Perbankan Syariah}

Bank syariah menganut prinsip-prinsip ekonomi Islam. Sehingga tidak boleh ada pemberian dan penerimaan bunga di dalam setiap transaksinya. ${ }^{14}$ Namun demikian secara umum produk yang dikeluarkan tidak hanya ditujukan untuk orang Islam saja. Karena lembaga ini hanya mengambil nilai-nilai keislaman yang kemudian dijadikan dasar dalam transaksi di lembaga tersebut. Terbukti dalam sejarah perkembangannya bank islam tidak hanya mendominasi Negaranegara yang mayoritas Bergama Islam, tetapi di sejumlah Negara yang masyarakatnya mayoritas non-Islam.

Apabila dibandingkan dengan total seluruh pangsa pasar perbankkan di Indonesia, presentase pangsa pasar dan aset perbankan syariah masih tergolong kecil. Namun demikian data statistik menunjukkan adanya peningkatan aset, Pembiayaan yang diberikan (PYD) dan Dana Pihak Ketiga (DPK) setiap tahunnya dengan rata-rata pertumbuhan aset 14,97\% dalam 5 tahun terakhir. Sementara itu pasar (market share) Perbankan Syariah per Desember 2020 sebesar 6,51\% dari seluruh market share bank konvensional. ${ }^{15}$

Secara kelembagaan industri perbankan syariah dapat dibagi menjadi tiga kelompok, yakni Bank Umum Syariah (BUS), Bank Pembiayaan Rakyat Syariah (BPRS) dan Unit Usaha Syariah (UUS). ${ }^{16}$ Menurut Undang-Undang Perbankan Syariah Bank Umum Syariah (BUS) ialah bank syariah yang kegiatannya memberikan jasa dalam lalu lintas pembayaran. Sebaliknya Pembiayaan Rakyat Syariah (BPRS) merupakan bank syariah yang dalam kegiatannya tidak memberikan jasa dalam lalu lintas pembayaran. Sedangkan Unit Usaha Syariah (UUS) merupakan unit kerja dari kantor pusat bank umum konvensional yang berfungsi sebagai kantor induk dari kantor aau unit yang melaksanakan kegiatan usaha berdasarkan syariah.

Selanjutnya ketiga lembaga ini dapat dipetakan ke dalam tabel Indikator Utama Perbankan Syariah sebagai berikut:

\section{Tabel 2.}

${ }^{14}$ Veithzal Rivai, Islamic Banking And Finance: Dari Teori Ke Praktik Bank Dan Keuangan Syariah Sebagai Solusi Dan Bukan Alternatif (Yogyakarta: BPFE, 2013), hlm. 95.

${ }^{15}$ Snapshot Perbankan Syariah OJK periode Desember 2020

${ }^{16}$ Neni Sri Imaniyati, Perbankan Syariah Dalam Perspektif Hukum Ekonomi (Bandung: CV. Mandar Maju, 2013), hlm. 63. 
Indikator Utama Perbankan Syariah Periode Desember 2020

\begin{tabular}{|c|c|c|c|c|c|}
\hline $\begin{array}{c}\text { Industri } \\
\text { Perbankan }\end{array}$ & $\begin{array}{c}\text { Jumlah } \\
\text { Institusi }\end{array}$ & $\begin{array}{l}\text { Jumlah } \\
\text { Kantor }\end{array}$ & $\begin{array}{c}\text { Aset } \\
\text { (Dalam } \\
\text { Triliun) }\end{array}$ & $\begin{array}{c}\text { Pyd } \\
\text { (Dalam } \\
\text { Triliun) }\end{array}$ & $\begin{array}{c}\text { Dpk } \\
\text { (Dalam } \\
\text { Triliun) }\end{array}$ \\
\hline $\begin{array}{l}\text { Bank } \\
\text { Umum } \\
\text { Syariah }\end{array}$ & 14 & 2.034 & 397,07 & 246,53 & 322,85 \\
\hline $\begin{array}{l}\text { Pembiayaan } \\
\text { Rakyat } \\
\text { Syariah }\end{array}$ & 20 & 392 & 196,88 & 137,41 & 143,12 \\
\hline $\begin{array}{l}\text { Unit Usaha } \\
\text { Syariah }\end{array}$ & 163 & 627 & 14,95 & 10,68 & 9,82 \\
\hline TOTAL & 197 & 3.053 & 608,90 & 394,63 & 475,79 \\
\hline
\end{tabular}

Secara umum perkembangan bank syariah hingga saat ini menganut dua pola. ${ }^{17}$ Pertama, pola pendirian bank syariah berupa bank syariah murni. Artinya semua produk yang diberikan oleh sebuah bank berdasarkna pada semua ketentuan syariah semata dan tidak ada satupun yang mendasarkan pada ketentuan bank konvensional. Hal ini banyak dilakukan oleh negara-negara Islam seperti Timur Tengah, meskipun tidak seluruh negara di kawasan menerapkan sistem perbankan syariah. Kedua, Dual Banking System yaitu bank membuka unit usaha syariah melalui Islamic Window dan sekaligus menjalankan usaha bank yang bersifat konvensional.

\section{Pertumbuhan dan Tigkat Penerimaan Masyarakat}

Pada awal pertumbuhan bank syariah ketangguhan sistem perbankan ini teruji ketika badai krisis melanda perekonomian Indonesia. Secara makro tingkat pertumbuhan ekonomi pada tahun 1997 turun di titik 4,91\% dari rata-rata pertumbuhan tiga tahun terakhir sebesar 7,9\%, bahkan pada triwulan III tahun 1998 pertumbuhan minus 17,13 \% ${ }^{18}$ Pada tahun ini kurang lebih 55 bank ditutup oleh pemerintah. Sementara dari 240 bank yang ada sebelum krisis moneter, hanya tersisa 73 bank swasta yang dapat bertahan tanpa bantuan pemerintah. ${ }^{19} \mathrm{Di}$ antaranya ialah bank Muamalat Indonesia yang mampu bertahan saat krisis ekonomi yang terjadi.

Pertumbuhan perbankan syariah menunjukkan adanya peningkatan sejak pertama dibedakan secara tegas dalam Undang-Undang Nomor 10 Tahun 1998 tentang Perbankan. Dalam undang-undang tersebut diatur dengan rinci landasan hukum serta jenis usaha yang dapat dioparasikan dan diimplementasikan oleh bank syariah. Di sisi lain undang-undang ini juga memberi arahan bagi bank-bank konvensional untuk membuka cabang syariah atau bahkan mengkorversi diri secara total menjadi bank syariah.

${ }^{17}$ Abdul Ghofur Anshori, Perbankan Syariah Indonesia, (Yogyakarta: Gadjah Mada Universitas), hlm, 28.

18 Noor Yudanto dan M. Setyawan Santoso, "Dampak Krisis Moneter terhadap Sektor Riil," Buletin Ekonomi dan Perbankan, September 1998, hlm. 132.

${ }^{19}$ Muhammad, Bank Syariah : Problem dan Prospek Perkembangan di Indonesia (Yogyakarta: Graha Ilmu, 2005), hlm.82 
Peluang ini kemudian disambut antusias oleh masyaakat perbankan. ${ }^{20}$ Beberapa di antara bank mulai memberikan pelatihan perbankan syriah kepada stafnya. Ada pula yang ingin menjajaki untuk membuka bank cabang syariah di lembaganya. Bahkan sebagian lainnya berencana mengkonversi diri sepenuhnya menjadi bank syariah.

Dalam perioda 1992-1998 hanya terdapat satu bank umum syariah dan 78 Bank Perkreditan Rakyat Syariah ( BPRS), sementara setelah amandemen tahun 1998 banyak berdiri bank syariah baru dengan sistem dual bangking system. Kemudian data terakhir menunjukkan ada sejumlah 197 lembaga perbankan syariah dengan 3.053 kantor di seluruh Indonesia. ${ }^{21}$ Lembaga ini meliputi Bank Umum Syariah, Bank Usaha Syariah dan Bank Pembiayaan Rakyat Syariah.

Data terakhir OJK per Desembe 2020 jumlah DPK mencapai Rp475,79 triliun dengan total rekening 36,43 juta. Sejauh ini data pengembangan aset, PYD dan DPK menunjukkan peninggkatan setiap tahunnya. Aset yang sebelumnya Rp.583 triliun (tahun 2019) naik ke Rp.609 triliun rupiah (periode 2020). Begitupula PYD di tahun 2019 senilai Rp.365 triliun naik menjadi Rp.395 triliun. Sementara DPK dari Rp.425 triliun menunjukkan peningkatan pula menjadi Rp.475 triliun.

Berikut diagram perkembangan dan grafik pertumbuhan perbankan syariah posisi Desember 2020: ${ }^{22}$

\section{Diagram 1.}

\section{Perkembangan Aset, (Pembiayaan Yang Diberikan) PYD dan (Dana Pihak Ketiga) DPK Periode Desember 2020}

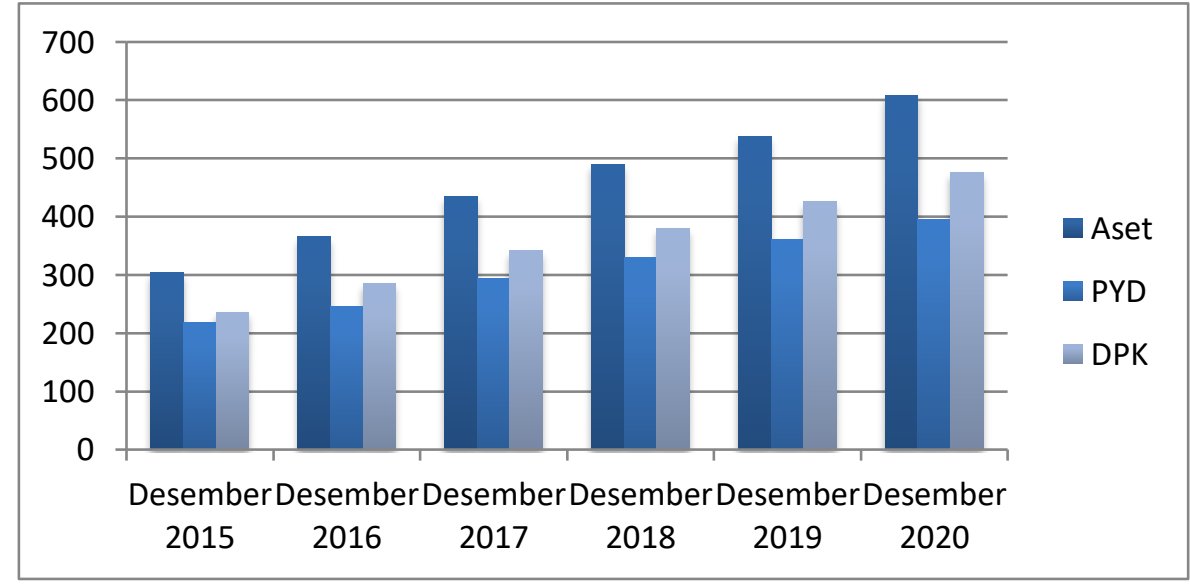

${ }^{20}$ Muhammad Syafi'i Antonio, Bank Syariah Suatu Pengenalan Umum (Bogor: BI Bekerja Sama dengan Tazkia Institute, 1999), hlm. 238

${ }^{21}$ Snapshot Perbankan Syariah OJK Per Juni 2019

22 Snapshot Perbankan Syariah OJK Posisi Desember 2020 
Sementara perkembangan pertumbuhan aset, PYD dan DPK dapat kita lihat sebagaimana data OJK posisi Desember 2020. Pertumbuhan aset mengalami penurunan sejak empat tahun terakhir. Pada tahun 2018 aset mencapai 12,57\% sedangkan 2019 turun sebesar 2,64\% menjadi 9,93\%. Akan tetapi pada 2020 mengalami kenaikan kembali menjadi 13,11\%. Sejalan dengan ini pertumbuhan PYD juga menurun dari 10,89\% pada 2019 menjadi 8,08\%. Selain itu, pertumbuhan DPK juga mengalami penurunan, tahun 2019 berada di titik 11,93\% kemudian 2021 menjadi 11,88\%. ${ }^{23}$ Artinya, disini pertumbuhan yang dinilai bagus untuk DPK yang dinilai memiliki perkembangan yang cukup stabil. Karena permintaan dan penawaran terhadap pembiayaan harus mempertimbangkan faktor likuiditas dalam penghimpunan. ${ }^{24}$ Semakin besar sumber dana yang terkumpul maka bank dapat menyalurkan pembiayaan dalam batas maksimum yang lebih besar pula. Namun tampaknya perkembangan DPK ini tidak diimbangi dengan PYD. Terbukti penurunan PYD dari tahun sebelumnya sekitar 2,81\%.

Kemudian perkembangan berdasarkan persentase sebaran aset perbankan syariah berdasarkan provinsi mengalami perkembangan naik turun. Setidaknya ada 10 provinsi dengan nilai aset terbesar dan lima daerah di antaranya memegang rekor selama tiga tahun terakhir ke dalam lima besar. ${ }^{25}$ Lima daerah ini di antaranya, DKI Jakarta, Jawa Barat, Jawa Timur, Nanggroe Aceh Darussalam dan Jawa Tengah. Berikut data terakhir perbankan syariah berdasarkan provinsi secara rinci berdasarkan laporan OJK 2019:26

Table 3.

Perkembangan Perbankan Syariah Berdasarkan Provinsi Tahun 2020

\begin{tabular}{|c|c|c|c|c|c|c|}
\hline $\begin{array}{c}\text { Kantor } \\
\text { Regional } \\
\text { OJK }\end{array}$ & Provinsi & $\begin{array}{c}\text { Pertumbuhan } \\
\text { Aset (yoy) }\end{array}$ & $\begin{array}{c}\text { Pertumbuhan } \\
\text { PYD (yoy) }\end{array}$ & $\begin{array}{c}\text { Pertumbuhan } \\
\text { DPK (yoy) }\end{array}$ & FDR & NPF \\
\hline $\mathbf{1}$ & Banten & $6,56 \%$ & $1,41 \%$ & $3,57 \%$ & $79,23 \%$ & $2,30 \%$ \\
\hline & $\begin{array}{c}\text { DKI } \\
\text { Jakarta }\end{array}$ & $11,47 \%$ & $3,58 \%$ & $4,43 \%$ & $79,67 \%$ & $2,32 \%$ \\
\hline $\mathbf{2}$ & Jawa Barat & $23,89 \%$ & $9,56 \%$ & $24,36 \%$ & $77,36 \%$ & $3,31 \%$ \\
\hline $\mathbf{3}$ & $\begin{array}{c}\text { DI } \\
\text { Yogyakarta }\end{array}$ & $16,47 \%$ & $3,54 \%$ & $14,57 \%$ & $61,24 \%$ & $4,49 \%$ \\
\hline & $\begin{array}{c}\text { Jawa } \\
\text { Tengah }\end{array}$ & $6,67 \%$ & $-3,19 \%$ & $18,05 \%$ & $79,73 \%$ & $7,90 \%$ \\
\hline $\mathbf{4}$ & $\begin{array}{c}\text { Jawa } \\
\text { Timur }\end{array}$ & $3,83 \%$ & $3,25 \%$ & $2,62 \%$ & $82,71 \%$ & $3,32 \%$ \\
\hline
\end{tabular}

${ }^{23}$ Ibid

${ }^{24}$ Imam Rifky Saputra, Pengaruh DPK dan NPF terhadap Pembiayaan yang Disalurkan (PYD) Serta Implikasinya pada ROA (Studi pada 3 Bank Umum SyariahdDi Indonesia Periode 2010-1013), Skripsi Fakultas Syariah Dan Hukum Uin Syarig Hidayatullah, 2014, 1m. 22

${ }^{25}$ Snapshot Perbankan Syariah OJK 2017, Snapshot Perbankan Syariah OJK Per Desember 2018 dan Snapshot Perbankan Syariah OJK Per Juni 2019, dan Snapshot Perbankan Syariah OJK Per Desember 2020

${ }^{26}$ Snapshot Perbankan Syariah OJK Periode Desember 2020 


\begin{tabular}{|c|c|c|c|c|c|c|}
\hline 5 & $\begin{array}{c}\text { Kepulauan } \\
\text { Riau }\end{array}$ & $7,00 \%$ & $2,83 \%$ & $14,96 \%$ & $127,69 \%$ & $1,90 \%$ \\
\hline & $\begin{array}{c}\text { Nanggroe } \\
\text { Aceh } \\
\text { Darussalam }\end{array}$ & $50,80 \%$ & $74,03 \%$ & $48,76 \%$ & $79,23 \%$ & $1,36 \%$ \\
\hline & Riau & $29,42 \%$ & $7,56 \%$ & $26,45 \%$ & $82,49 \%$ & $2,20 \%$ \\
\hline & $\begin{array}{c}\text { Sumatera } \\
\text { Barat }\end{array}$ & $16,50 \%$ & $2,88 \%$ & $19,42 \%$ & $74,69 \%$ & $2,52 \%$ \\
\hline & $\begin{array}{l}\text { Sumatera } \\
\text { Utara }\end{array}$ & $9,46 \%$ & $6,34 \%$ & $11,25 \%$ & $77,77 \%$ & $9,30 \%$ \\
\hline \multirow[t]{10}{*}{6} & Gorontalo & $15,84 \%$ & $19,01 \%$ & $9,92 \%$ & $111,86 \%$ & $2,48 \%$ \\
\hline & Maluku & $12,29 \%$ & $15,22 \%$ & $13,43 \%$ & $46,31 \%$ & $0,77 \%$ \\
\hline & $\begin{array}{l}\text { Papua } \\
\text { Utara }\end{array}$ & $22,00 \%$ & $19,55 \%$ & $25,29 \%$ & $67,93 \%$ & $0,41 \%$ \\
\hline & Papua & $2,75 \%$ & $4,61 \%$ & $7,79 \%$ & $64,36 \%$ & $3,78 \%$ \\
\hline & $\begin{array}{l}\text { Papua } \\
\text { Barat }\end{array}$ & $11,65 \%$ & $-0,47 \%$ & $14,60 \%$ & $25,37 \%$ & $3,68 \%$ \\
\hline & $\begin{array}{c}\text { Sulawesi } \\
\text { Barat }\end{array}$ & $21,85 \%$ & $25,45 \%$ & $8,03 \%$ & $170,57 \%$ & $0,79 \%$ \\
\hline & $\begin{array}{l}\text { Sulawesi } \\
\text { Selatan }\end{array}$ & $8,67 \%$ & $8,03 \%$ & $11,48 \%$ & $113,08 \%$ & $4,11 \%$ \\
\hline & $\begin{array}{c}\begin{array}{c}\text { Sulawesi } \\
\text { Tengah }\end{array} \\
\end{array}$ & $5,44 \%$ & $10,28 \%$ & $4,07 \%$ & $140,63 \%$ & $1,75 \%$ \\
\hline & $\begin{array}{l}\text { Sulawesi } \\
\text { Tenggara }\end{array}$ & $25,48 \%$ & $16,76 \%$ & $24,41 \%$ & $100,98 \%$ & $3,13 \%$ \\
\hline & $\begin{array}{c}\text { Sulawesi } \\
\text { Utara }\end{array}$ & $27,66 \%$ & $30,30 \%$ & $15,16 \%$ & $207,61 \%$ & $1,72 \%$ \\
\hline \multirow[t]{5}{*}{7} & $\begin{array}{l}\text { Bangka } \\
\text { Belitung }\end{array}$ & $21,24 \%$ & $27,46 \%$ & $9,68 \%$ & $82,88 \%$ & $0,96 \%$ \\
\hline & Bengkulu & $11,93 \%$ & $10,40 \%$ & $23,20 \%$ & $132,13 \%$ & $3,98 \%$ \\
\hline & Jambi & $15,46 \%$ & $7,07 \%$ & $37,92 \%$ & $130,83 \%$ & $2,55 \%$ \\
\hline & Lampung & $13,01 \%$ & $7,69 \%$ & $14,09 \%$ & $102,05 \%$ & $2,49 \%$ \\
\hline & $\begin{array}{l}\text { Sumatera } \\
\text { Selatan }\end{array}$ & $14,44 \%$ & $8,06 \%$ & $15,14 \%$ & $99,19 \%$ & $4,24 \%$ \\
\hline \multirow[t]{3}{*}{8} & Bali & $-8,66 \%$ & $3,09 \%$ & $-2,12 \%$ & $162,00 \%$ & $6,03 \%$ \\
\hline & $\begin{array}{c}\text { Nusa } \\
\text { Tenggara } \\
\text { Barat }\end{array}$ & $23,98 \%$ & $15,37 \%$ & $11,89 \%$ & $104,46 \%$ & $1,47 \%$ \\
\hline & $\begin{array}{c}\text { Nusa } \\
\text { Tenggara } \\
\text { Timur } \\
\end{array}$ & $17,96 \%$ & $17,48 \%$ & $8,48 \%$ & $138,84 \%$ & $1,12 \%$ \\
\hline \multirow[t]{2}{*}{9} & $\begin{array}{c}\text { Kalimantan } \\
\text { Barat }\end{array}$ & $9,87 \%$ & $10,71 \%$ & $14,06 \%$ & $154,41 \%$ & $1,39 \%$ \\
\hline & $\begin{array}{c}\text { Kalimantan } \\
\text { selatan }\end{array}$ & $12,84 \%$ & $-0,06 \%$ & $11,66 \%$ & $72,17 \%$ & $3,07 \%$ \\
\hline
\end{tabular}




\begin{tabular}{|c|c|c|c|c|c|c|}
\hline & $\begin{array}{c}\text { Kalimantan } \\
\text { Tengah }\end{array}$ & $5,33 \%$ & $2,30 \%$ & $17,43 \%$ & $132,46 \%$ & $1,77 \%$ \\
\hline & $\begin{array}{c}\text { Kalimantan } \\
\text { Timur }\end{array}$ & $10,64 \%$ & $7,77 \%$ & $15,29 \%$ & $72,31 \%$ & $5,35 \%$ \\
\hline $\begin{array}{c}\text { Luar } \\
\text { Indonesia }\end{array}$ & $24,85 \%$ & $15,98 \%$ & $13,70 \%$ & $63,17 \%$ & $0,00 \%$ \\
\hline
\end{tabular}

Sehubungan dengan perkembangan bank syariah di Indonesia, penerimaan masyarakat terhadap sistem juga menjadi topik yang menarik. Karena sikap masyarakat terbagi menjadi dua kubu. Sebagian masyarakat menyambut dengan antusias dan sebagian lain sebaliknya. Mereka yang menyambut baik karena terdapat unsur syariah di dalamnya, dimana mayoritas masyarakat Indonesia beragama Islam. Sehingga diharapkan melalui sistem ini akan dapat menjalankan transaksi perbankan dengan prinsip syariah dan terhindar dari praktik bunga bank yang dianggap riba.

Sementara di sisi lain perkembangan dan pertumbuhan bank syari'ah tersebut dipandang sinis oleh beberapa kalangan, bahkan kalangan umat Islam sendiri. Sinisme terhadap perbankan Islam tersebut dapat dilihat dari kepercayaan masyarakat Islam terhadap Bank Syari'ah sangat rendah. Hal tersebut dapat dilihat dari partisipasi umat Islam dalam investasi atau perguliran modal. Lebih tegas lagi, Sutan Remy menyatakan bahwa pengamatan atau penelitian beberapa ilmuwan Islam menyebutkan bahwa bank-bank Islam dalam penyelenggaraan kegiatan usahanya, ternyata bukan meniadakan bunga dan membagi risiko, tetapi mempertahankan praktek pembebanan bunga. Dengan kata lain, menghindarkan risiko dengan cara mencari celah di antaranya. $^{27}$

Ada beberapa faktor problematika perkembangan bank syariah di masyarakat. Seperti faktor sosial, ekonomi, politik, hukum, lingkungan serta teknologi. Dalam hal ini faktor sosial menjadi faktor yang paling berpengaruh bagi masyarakat. Di antaranya kepercayaan, nilai, sikap hingga pada gerakan keagamaan. ${ }^{28}$ Selain itu, banyak faktor yang menyebabkan umat Islam belum berhubungan atau bertransaksi dengan bank syariah. Pertama, tingkat pengetahuan dan pemahaman umat tentang bank syariah masih sangat rendah, kedua peran ulama dan dai' masih relatif kecil, ketiga peran akademisi perguruan tinggi belum optimal, dan keempat peran ormas Islam juga belum optimal membantu dan mendukung gerakan Bank Syariah. ${ }^{29}$

Di sisi lain problematika bagi masyarakat yang tidak kalah penting adalah aksesibilitas layanan maupun produk bank syariah yang terbatas. Beberapa orang menganggap kurang efisien hlm. 20.

${ }^{27}$ Amir Mu'allim, "Persepsi Masyarakat terhadap Lembaga Keuangan Syariah," Al-Mawarid Edisi X (2003),

${ }^{28}$ Muhammad, Bank Syariah : Problem dan Prospek Perkembangan...hlm. 42.

${ }^{29}$ Abdul Hadi Sirat, "Persepsi Masyarakat terhadap Perbankan Syariah di Kota Makassa," Al-Qalam Vol. 16 No. 26 (Juli - Desember 2010), hlm. 157. 
karena jaringan perusahaan yang dimiliki bank syariah tidak sebanyak dan seluas bank konvensional. ${ }^{30}$ Sehingga hal ini turut mempengaruhi keputusan masyarakat dalam memilih bank konvensional atau bank syariah.

Berikut sebagai salah satu contoh penerimaaan masyarakat secara positif lembaga bank syariah sebagaimana hasil penelitian Nanda Harry Mardika dan Raymond di Batam. ${ }^{31}$ Faktorfaktor yang mempengaruhi keputusan nasabah dalam menabung di bank syariah Di kota Batam berdasarkan hasil pengujian dengan menggunakana analisis Cochran Q Test maka dapat ditarik kesimpulan sebagai berikut: (1) Untuk Variabel Eksternal indikator yang mempengaruhi keputusan nasabah dalam menabung di bank syariah Di kota Batam adalah: (a) Faktor budaya pada indikator, Kebudayaan Negara; (b) Faktor promosi pada indicator, Kemudahan; (2) Variabel Internal: (a) Faktor pelayanan pada indikator, Kesopanan para pegawai; (b) Faktor fasilitas pada indikator, ATM.

Sementara di sisi lain tidak sepenuhnya masyarakat memandang bahwa lembaga keuangan syari'ah, terutama bank mempunyai dampak negatif terhadap perkembangan ekonomi. Hal ini dikarenakan terjadi kasus-kasus yang menorehkan tinta hitam pada perkembangan lembaga keuangan Islam. Misalnya, di daerah Kalimantan pernah didirikan Lembaga keuangan syari'ah yang modalnya diambil dari bank konvensional yang besar. Sekitar satu tahun kemudian lembaga tersebut kolaps dan pemiliknya tidak bertanggungjawab atas kredit macetnya. Pemilik dan penanggungjawab lembaga keuangan syari'ah tersebut melarikan diri.

Kasus-kasus tersebut tidak hanya terjadi sekali, namun terjadi berulang kali di tempat lain, seperti terjadi kasus di Tegal pada lembaga keuangan tersebut menerapkan sistem mudharabah muqayyadah fi an-nisbah bi al miyyah, yaitu asumsi perhitungan nisbah yang ditetapkan $2.5 \%$ berdasar jumlah pembiayaan yang dikelurkan, sehingga mekanisme ini menyerupai perhitungan bunga. Walaupun tidak separah seperti kasus di Kalimantan, namun hal tersebut mempengaruhi persepsi masyarakat terhadap lembaga keuangan syariah, terutama tingkat kepercayaan masyarakat. $^{32}$

\section{Penutup}

Praktik Perekonimian Islam sudah ada sejak masa Rasulullah saw. Sejarah ini kemudian berlanjut hingga ke dunia Eropa. Namun kemudian sempat terputus karena bangsa Eropa menjalankan praktik perbankan menggunakan instrumen bunga. Ketika mengalami masa renaissance bangsa Eropa melakukan penjajahan ke seluruh penjuru dunia, sehingga aktivitas perekonomian dunia didominasi oleh bangsa-bangsa Eropa.

Hingga akhirnya lahirlah kembali cikal bakal penerapan sistem ekonomi syariah yang mulai dilakukan di Pakistan dan Malaysia sekitar tahun 1940-an. Yakni pengelolaan dana haji

${ }^{30}$ Mustika Delima dan Metti Paramita, "Analisis Kemudahan Akses terhadap Kepercayaan Masyarakat pada Bank Syariah (Studi Bank BRI Syariah Palabuhanratu,” Jurnal Nisbah, Vol.5 No.1 (2019), hlm. 81.

${ }^{31}$ Nanda Harry Mardika dan Raymond, "Analisis Persepsi Masyarakat Dalam Memilih Perbankan Syariah Di Kota Batam,” Seminar Nasional Ilmu Sosial dan Teknologi 1 (23 Agustus 2018), hlm. 119.

${ }^{32}$ Amir Mu’allim, “Persepsi Masyarakat terhadap Lembaga Keuangan Syariah...hlm. 24. 
dengan sistem melalui profit and loss sharing. Kemudian berlanjut pada pendirian bank syariah pertama yakni pendirian Islamic Rural Bank di desa Mit Ghamr Mesir tahun 1963.

Salah satu tonggak perkembangan perbankan syariah adalah didirikannya Islamic Development Bank (IDB) pada bulan Oktober 1975 yang berpusat di Jeddah. Sejak berdirinya IDB ini kemudian muncul bank-bank Islam di seluruh dunia. Termasuk di kawasan Eropa dan Asia. Sementara itu di Indonesia, secara kelembagaan Bank Islam pertama ialah Bank Muamalat Indonesia (BMI). Bank ini didirikan pada tahun 1991. Meskipun pemikiran mengenai pendirian bank ini sudah ada sejak tahun 1980-an ${ }^{33}$, namun kemudian baru terealisasi pada tahun 1991. Pada masa itu beberapa uji coba dengan skala terbatas telah dilakukan. Di antaranya pendirian Baitu Tamwil-Salman di Bandung dan koperasi Ridho Gusti di Jakarta.

Hingga saat ini data terakhir menunjukkan ada sejumlah 197 lembaga terkait perbankan syariah dengan 3.053 kantor di seluruh Indonesia. ${ }^{34}$ Lembaga ini meliputi Bank Umum Syariah, Bank Usaha Syariah dan Bank Pembiayaan Rakyat Syariah.

Apabila dibandingkan dengan total seluruh pangsa pasar perbankkan di Indonesia, presentase pangsa pasar dan aset perbankan syariah masih tergolong kecil. Namun demikian data statistik menunjukkan adanya peningkatan aset, Pembiayaan yang diberikan (PYD) dan Dana Pihak Ketiga (DPK) setiap tahunnya dengan rata-rata pertumbuhan aset 14,97\% dalam 5 tahun terakhir. Sementara itu market share perbankan syariah hanya 6,51\% dari seluruh market share bank konvensional.

Sesuai Indikator Utama Perbankan Syariah Per Juni 2019 terdapat 197 institusi meliputi Bank Umum Syariah, Bank Usaha Syariah dan Bank Pembiayaan Rakyat Syariah dengan 3.053 jumlah kantor di seluruh Indonesia. Dari data terakhir ini diketahui nilai aset mencapai 608,90 triliun, PYD Rp. 394,63 triliun dan DPK Rp. 475,79 triliun.

Dilihat dari segmentasinya, Bank syariah menganut prinsip-prinsip ekonomi islam. Namun secara umum produk yang dikeluarkan tidak hanya ditujukan untuk orang islam saja. Karena lembaga ini hanya mengambil nilai-nilai keislaman yang kemudian dijadikan dasar dalam transaksi di lembaga tersebut. Terbukti dalam sejarah perkembangannya bank islam tidak hanya mendominasi Negara-negara yang mayoritas Bergama Islam, tetapi di sejumlah Negara yang masyarakatnya mayoritas non-Islam

Mengenai pertumbuhan dan tingkat penerimaan masyarakat, hingga saat ini OJK mencatat jumlah rekening PYD perbankan syariah mencapai 5,89 juta per Desember 2020. Sementara rekening Dana Pihak Ketiga (DPK) mencapai 36,43 juta dengan total DPK selama tahun berjalan 2020 mencapai Rp475,79 triliun. Sejauh ini data pengembangan aset, PYD dan DPK menunjukkan peninggkatan setiap tahunnya. Aset yang sebelumnya Rp.583 triliun (tahun 2019) naik ke Rp.609 triliun rupiah (periode 2021). Begitupula PYD di tahun 2019 senilai Rp.365 triliun naik menjadi Rp.395 triliun. Sementara DPK dari Rp.425 triliun menunjukkan peningkatan pula menjadi Rp.475 triliun.

\footnotetext{
${ }^{33}$ Muhammad Sadi Is, Konsep Hukum Perbankan Syariah...hlm. 30.

${ }^{34}$ Snapshot Perbankan Syariah OJK per Juni 2019
} 
Pertumbuhan aset mengalami penurunan sejak empat tahun terakhir. Pada tahun 2018 aset mencapai 12,57\% sedangkan 2019 turun sebesar 2,64\% menjadi 9,93\%. Akan tetapi pada 2020 mengalami kenaikan kembali menjadi $13,11 \%$. Sejalan dengan ini pertumbuhan PYD juga menurun dari 10,89\% pada 2019 menjadi 8,08\%. Selain itu, pertumbuhan DPK juga mengalami penurunan, tahun 2019 berada di titik 11,93\% kemudian 2021 menjadi 11,88\%. Artinya, disini pertumbuhan yang dinilai bagus untuk DPK yang dinilai memiliki perkembangan yang cukup stabil. Karena permintaan dan penawaran terhadap pembiayaan harus mempertimbangkan faktor likuiditas dalam penghimpunan. Semakin besar sumber dana yang terkumpul maka bank dapat menyalurkan pembiayaan dalam batas maksimum yang lebih besar pula. Namun tampaknya perkembangan DPK ini tidak diimbangi dengan PYD. Terbukti penurunan PYD dari tahun sebelumnya sekitar $2,81 \%$.

Sedangkan penerimaan masyarakat terhadap sistem perbankan syariah ini juga bervariasi. Sikap masyarakat terbagi menjadi dua kubu. Sebagian masyarakat menyambut dengan antusias dan sebagian lain sebaliknya. Mereka yang menyambut baik karena terdapat unsur syariah di dalamnya, dimana mayoritas masyarakat Indonesia beragama Islam. Sehingga diharapkan melalui sistem ini akan dapat menjalankan transaksi perbankan dengan prinsip syariah dan terhindar dari praktik bunga bank yang dianggap riba. Sementara di sisi lain masyarakat bersikap kontra terhadap bank syariah, terutama bank mempunyai dampak negatif terhadap perkembangan ekonomi. Hal ini dikarenakan terjadi kasus-kasus yang menorehkan tinta hitam pada perkembangan lembaga keuangan Islam. 


\section{DAFTAR PUSTAKA}

Antonio, Muhammad Syafi'i, Bank Syariah Suatu Pengenalan Umum, Bogor: BI Bekerja Sama dengan Tazkia Institute, 1999.

Anshori, Abdul Ghofur, Perbankan Syariah Indonesia, Yogyakarta: Gadjah Mada Universitas.

Dahlan, Ahmad, Bank Syariah: Teoritik, Praktik, Kritik, Yogyakarta, Teras, 2012.

Delima, Mustika dan Metti Paramita, "Analisis Kemudahan Akses terhadap

Kepercayaan Masyarakat pada Bank Syariah (Studi Bank BRI Syariah

Palabuhanratu," Jurnal Nisbah, Vol.5 No.1, 2019.

Karim, Adiwarman, Bank Islam: Analisis Fiqih dan Keuangan, Jakarta: PT. Raja Grafindo, 2007.

Mardika, Nanda Harry dan Raymond, "Analisis Persepsi Masyarakat Dalam Memilih Perbankan Syariah Di Kota Batam," Seminar Nasional Ilmu Sosial dan Teknologi 1, 23 Agustus 2018.

Huda, Nurul dan Mohamad Heykal, Lembaga Keuangan Islam: Tinjauan Teoritis dan Praktis,Jakarta: Kencana, 2010.

Is, Muhammad Sadi, Konsep Hukum Perbankan Syariah: Pola Relasi Sebagai Institusi Intermediasi dan Agen Investasi, Malang: Setara Press, 2015.

Imaniyati, Neni Sri, Perbankan Syariah Dalam Perspektif Hukum Ekonomi, Bandung: CV. Mandar Maju, 2013.

Muhammad, Bank Syariah : Problem dan Prospek Perkembangan di Indonesia, Yogyakarta: Graha Ilmu, 2005.

Mu'allim, Amir, "Persepsi Masyarakat terhadap Lembaga Keuangan Syariah," AlMawarid Edisi X, 2003.

Saputra, Imam Rifky, Pengaruh DPK dan NPF terhadap Pembiayaan yang Disalurkan (PYD) Serta Implikasinya pada ROA (Studi pada 3 Bank Umum SyariahdDi Indonesia Periode 2010-1013), Skripsi Fakultas Syariah Dan Hukum Uin Syarig Hidayatullah, 2014.

Sirat, Abdul Hadi, "Persepsi Masyarakat terhadap Perbankan Syariah di Kota Makassa," Al-Qalam Vol. 16 No. 26, Juli - Desember 2010.

Sutrisno, Hadi, Metodologi Research, Yogyakarta: Andi Offse, 1990.

"Per Agustus 2019, jumlah rekening simpanan di bank mencapai 292,96 juta rekening," https://keuangan.kontan.co.id/news/per-agustus-2019-jumlahrekening-simpanan-di-bank-mencapai-29296-juta-rekening?page=all diakses tanggal 10 Maret 2010.

"Per Oktober, OJK Catat Jumlah Nasabah Bank Syariah Capai 31,89 Juta," https://www.merdeka.com/uang/per-oktober-ojk-catat-jumlah-nasabah-bank-syariahcapai-3189-juta.html diakses tanggal 9 Maret 2020.

Rivai, Veithzal, Islamic Banking And Finance: Dari Teori Ke Praktik Bank Dan Keuangan Syariah Sebagai Solusi Dan Bukan Alternatif, Yogyakarta: BPFE, 2013

Seomitra, Andri, Bank dan Lembaga Keuangan Syariah, Jakarta: Kencana, 2009. 
Snapshot Perbankan Syariah OJK Tahun 2017

Snapshot Perbankan Syariah OJK Per Desember 2018

Snapshot Perbankan Syariah OJK Per Maret 2019

Snapshot Perbankan Syariah OJK Per Juni 2019

Snapshot Perbankan Syariah OJK Per Desember 2020

Undang-Undang Nomor 21 Tahun 2008 tentang Perbankan Syariah

Undang-Undang Nomor 10 Tahun 1998 tentang perubahan atas Undang-Undang

Nomor 7 Tahun 1992 tentang Perbankan.

Yudanto, Noor dan M. Setyawan Santoso, "Dampak Krisis Moneter terhadap Sektor Riil,” Buletin Ekonomi dan Perbankan, September 1998. 